\title{
CEO Duality and Firm Distress
}

\author{
Georgios Kolias, Nikolaos Arnis, Efstratios Kypriotelis \\ Department of Accounting and Finance, University of Ioannina, Ioannina, Greece \\ Email:koliasg@otenet.gr, narnis@teiep.gr,kypriot@gmail.com
}

How to cite this paper: Kolias, G., Arnis, N. and Kypriotelis, E. (2019) CEO Duality and Firm Distress. Open Journal of Accounting, 8, 19-34.

https://doi.org/10.4236/ojacct.2019.82002

Received: March 20, 2019

Accepted: April 27, 2019

Published: April 30, 2019

Copyright $\odot 2019$ by author(s) and Scientific Research Publishing Inc. This work is licensed under the Creative Commons Attribution International License (CC BY 4.0).

http://creativecommons.org/licenses/by/4.0/

\begin{abstract}
This study examines the relationship between firm performance and corporate governance structure, mainly leadership structure. The leadership structure is strongly related to CEO duality. There are several aspects and dimensions of this relation, which may influence the corporate performance but this study focuses on the extreme situation where this relation reaches its ends, namely the corporation collapse. This paper has considered the factors that can cause corporate failure and its governance inability to attain their objectives. Data were collected from 385 bankrupt and 14.000 non-bankrupt unlisted Greek firms for a period of ten years in order for a model to be drawn, indicating the possibility of those firms incorporated under duality to bankrupt.
\end{abstract}

\section{Keywords}

CEO Duality, Financial Distress, Average Treatment Effects

\section{Introduction}

Since the second half of the 20th century, a long debate on CEO and Chairman Duality (referred to as CEO duality) and its impact on firm performance has been taking place [1] [2]. Additionally, this field of study has grown significantly and today contains a great proliferation of theories, approaches and researches in various countries and corporations [3]. The reasons contributed to the recent corporate failures, in various countries around the world were connected with the quality of leadership. The corporate performance led to renewed campaigns for governance reforms. The recent literature attempts to define the nature and extends of the dilemmas faced by corporations concerning the structure of corporate governance.

One of the main issues refers to the CEO duality, the practice of one person serving as both CEO and board chair and has been the subject of academic interest for more than 25 years. Many studies address the issue of consolidating or splitting the CEO and Chairman positions. The original form of modern busi- 
ness organization was the small firm in which the ownership and management coincided. The development of the modern corporations begins with the joint-stock company, in which individual ownership moves towards social ownership. The joint-stock company is a higher form of ownership than private ownership of the means of production. It marginalizes the individual owner and replaces him with managers, who are bureaucratic employees. The objectives of the study are to investigate the relationship between CEO duality and the firm performance and how they are linked to business control. The article is built in the previous literature. Reviewing the literature, there is a lot of information or context-specific research on the above relationship, based on which, the study criticizes it or gives a different view and aspect to the events. Thus, in our study, we test the hypothesis of the effect of CEO Duality on firm bankruptcy without, initially, making suggestions concerning the sign of the effect.

Hence, the main contribution of the study is that while many studies investigate the relation between firm performance and corporate governance structure, this study focuses on the impact of corporate governance structure on firm financial distress. This study is also notable, in providing a model of the relationship between firm distress and CEO duality, considering the possibility of firms' bankruptcy, all other factors being equal. More specifically, we use Average Treatment Effects (ATE) methodology to estimate the effect of CEO duality on the probability of firm distress. To be more specific, an augmented inverse-probability weighted (AIPW) estimator is used to identify and estimate the parameters of the potential-outcome distributions. In causal inference settings, doubly robust estimators involve models for both the propensity score and the conditional mean of the outcome. Because of the double-robust property, only one of these two models must be correctly specified for the AIPW estimator to be consistent.

The results of this study will help interested parties to take into consideration the qualitative characteristics of internal control and the relationship between CEO, chairman and board of directors and the internal control, specifically the control over the quality of accounting information.

The paper is organized as follows: Section 2 introduces terminology used throughout this paper. Sections 3 to 5 describe the relations between the issues of the state of the corporate governance structure, the board members and control of the management. Section 6 presents the data as well as the methodology used in the article. We conclude the paper in Section 7.

\section{Conceptual Issues}

The Chief Executive Officer (CEO) is at the head of management, conducting and supervising actions with the prudential use of means to accomplish the corporate aims. The Chairman is responsible for the leadership and is pivotal in the creation of the conditions necessary for collective and individual performance of all corporate members and workers. It is also the Chairman's responsibility to ensure effective communication between the board members and control of the management. In our analysis, we rely on terminology derived from [4]: the defi- 
nition of dual leadership structure, the case when the two positions are held by two individuals. CEO duality would refer to the situation where the CEO holds both titles, so that using unitary leadership (structure) to refer to a single $\mathrm{CEO} /$ Chairman and dual leadership to refer to two leaders is most descriptive.

\section{Literature on CEO and Chairman Duality and Control}

The issue of governance of the enterprise is connected with the organizational structure within which the functional roles should be clearly defined. Governance of the enterprise is a concept of historically evolving content. Pre-19th-century notions of the governance of the enterprise were based on trust, namely that the stewards of the firm could be trusted to make the best use of the assets of the organization on behalf of the owners [5]. In the original form of modern business, the owner and the manager coincide. The considerations that impel the owner to decide among alternatives could not conflict with his interest as a manager. Economic development and crises in the 19th century led to a direct reaction within the system.

Crises break out in the economic system in different forms and on different levels. The first major crisis broke out in the bases of ownership, the small enterprise and small industry. When crises break out or are transferred to the bases of the system, the terms of production change. Crises arise in the different spheres of social life and society as a whole in various forms and levels of intensity. The joint-stock company is the product of these crises, specifically the crisis of individual ownership. The individual business owner was no longer necessary to the economic system because he could not meet the demands of economic development; not through his own incompetence but due to the demands of economic development, which moves up through each level towards the socialization of production. The result was a change in ownership relations to the benefit of the joint-stock corporation. The level of management of the economy also changes, since big capital is more progressive, more socialized and has more developed management forms, which each enterprise incorporates as an internal organic process [6]. One innovation is that management raises a level, causing the separation of ownership and management. A dialectical relationship is formed between ownership and management, as the enterprise rises from the level of an individual owner to a joint-stock enterprise. Under the new conditions, the private interest of the hired managers (and the controlling group) need no longer coincide at all points with the interest of the stockholder-owners [7]. This renders it necessary to provide a deeper critical evaluation of the essence of the relationships that create the characteristics of ownership and management relations. Bearn and Means concluded from their study that "the controlling group, even if they own a large block of stock, can serve their own pockets better by profiting at the expense of the company than by making profits for it" [7] This is precisely the issue of control, connecting with the duality of leadership, when the CEO is also chairman.

When the CEO is also chairman, management has de facto control. Yet the 
board is supposed to be in charge of management. Checks and balances have been thrown to the wind.

The issue of external and internal control becomes central, and to a certain extent has become a question of corporation survival. The control changes from purely quantitative to qualitative and purely qualitative, with the need to determine the methods of measuring the quality characteristics of the corporation organizational structure. [8] states that corporate governance is about to control and running of companies, where the issue of control is raised, concerning to the duration, the range of activities and to who exercises the control of the firm. Governance and control recommend the corporate structure should be balanced and the autonomy of the two. Decisions should be made concerning the awarding of profit in such a way as to benefit the claims of the controlling group, the awarding of bonuses and benefits to management and ownership.

The existing empirical evidence from various countries and for different time periods, covering the last three decades appears to support the separation of CEO and chairman titles. But in their study [4] give contradicting arguments against separate leadership. They argue that this separation has potential costs, as well as potential benefits. [9] In their study of corporate governance mention between others:

Corporate governance mechanisms are economic and legal institutions that can be altered through the political process-sometimes for the better. One could take a view that we should not worry about governance reform, since, in the long run, product market competition would force firms to minimize costs, and as part of this cost minimization to adopt rules, including corporate governance mechanisms, enabling them to raise external capital at the lowest cost. On this evolutionary theory of economic change, competition would take care of corporate governance. While we agree that product market competition is probably the most powerful force towards economic efficiency in the world, we are skeptical that it alone can solve the problem of corporate governance.

When issues of control arise then a market cannot be the regulating mechanism by assumption or by construction and rules come to be established as institutions emerge to place limits on the personal behavior of managers. In essence, corporate governance deals with the assurance of shareholders to get a profit from their investment. Profits are the criterion of managerial performance and accountant is of crucial importance in handling the accounting information in such a way to the benefit of the manager. Accounting is, therefore, a basic element in company administration, management and control. Defining corporate governance, [10] had appointed distinctive roles to the management and control, because management is about running a business, and governance of the corporation is about controlling that corporation functions properly. Hence corporate governance is concerned with management, governance and control, specifying the distribution of rights and responsibilities among different participants.

${ }^{1}$ From: “Stockholders want Boards of Independents", USA Today, Money Section, May 14, 1993. 


\section{Unity of Command and Accounting}

The managerial function is expressed through the members of the organization, that is, through the body corporate. The appropriateness and performance of the body corporate is a function of particular laws and conditions governing the operation of the business. These laws and conditions are also referred to as principles. The unity of command is one of those principles, addressing that a command is received from one superior only. Unity of command is one of the most important issues of corporate governance with substantial influence in business performance. Because of the differences between the duality and unitary corporate governance, we should expect that the precise forms that the CEO-Chairman conflict takes would be different in small or large enterprises. In large enterprises, the accountant is of crucial importance in handling the data of the enterprise in such ways as make the best possible case for the CEO. The accounting techniques could be an instrument of creative accounting, involving the failure to deduct depreciation, charging to capital expenses which properly should be charged against income account, figuring out ways to hide large expenditure and creation of hidden reserves.

The CEO of a body corporate carries out the role of Chief Accounting Officer and to extend that the auditing functions are based on accounting data the CEO is the auditor and the auditee. It is, therefore, understandable that since there is duality, the control over enterprise is more of hands of CEO/Chairman. He is conducting and supervising actions both as CEO and as the policy or lawmaker of the enterprise. Through this development the duality leadership reduces control, delivering implications on accounting management, concerning the corporate governance and the corporate performance there from. This, rather than majority rule, seems to be the base, the reference point from which further discussion and theorizing about duality and control of corporate must begin. Poor corporate governance is by definition one of the most important reasons for corporate failure [4], providing evidence that firms with separate titles outperform firms with combined titles. As this debate has been widely reviewed, the corporate governance provides the structure through which the company's objectives are set and the strategies, the tactics and the means, of attaining those objectives and monitoring performance defined and the corporate governance is strongly related and affected or not from $\mathrm{CEO} /$ chairman duality. But this is not the central issue. The central issue is the critical interdependence between control and the informational content of this process which can only be revealed as the process is allowed to occur. In other words, it could be an accounting "hidden information", difficult to audit that may drive a corporation to bankruptcy and that this "hidden information" is more difficult to be revealed when there is $\mathrm{CEO} /$ chairman duality.

In one sense, it becomes misleading at the outset to say that managers act as if they were maximizing their benefit, since this terminology tends to suggest that the managers' benefit exist independently of their governance process. It is better at this level of discussion, to say simply that CEO or chairman choose among 
alternatives as they arise, pursuing the shareholders' interest, and that there is, enough consistency in their behavior to allow them to align their benefit with corporate performance. In current literature prevails the notion of misalignment between the interest of shareholder and that of the management [9]. In time of crises, it is clear that profit plays a minor role, compared with bonuses ${ }^{2}$, as a managerial incentive. Managers run the company and focus their attention on their own interest first. The CEO shares directly in profit to a limited extent, and often his decisions are based on different aims. The CEO not infrequently tends to consider the shareholders as outsider.

Promoting the opposite point of view, we are arguing that despite there is or not alignment between the interest of shareholders and that of the managers, key role plays controlling the CEO's managerial assignment. Control increases security procedures that the corporation's assets are being protected so that risks are eliminated or minimized. Management is ultimately responsible for determining whether or not control is functioning effectively and in the case of the governance practices, control has an impact on shareholders, investors and the public, indeed on all stakeholders. In essence, adequate control over manager practices generates investor confidence and goodwill. [11] claim that splitting titles would dilute their power to provide effective leadership create the potential for rivalry between the separate title holders and that having two public spokespersons could well lead to confusion and even to opportunistic behavior by outsiders [4].

Contrary to the allegations, combining the CEO and chairman titles reduces the effectiveness of control. In this process an important responsibility is that of accurate reporting of the corporation financial wealth, rendering stewardship accounting inevitable. It is, therefore, a basic element in company management and control. Furthermore, accounting generates the essential data giving the picture of the condition of the corporation that CEO and chairman use in strategic decisions. Corporation's complex financial statements are confusing to shareholders and even analysts. Enron-type scandal is a recent paradigm, lending to renewable campaigns for governance reform, including calls for the separation of CEO and chairman positions. Enron unified the titles of CEO and chairman and its accounting had been fairly straightforward. Enron adopted approved accounting methods in its trading of natural gas future contracts expanded its use to other areas in the company without the right to do so. When CEO and chairman duality split, the new CEO changed the accounting method, anticipating future profits from any deal were accounted for by estimating their present value rather than historical cost. Merging the two titles again, Enron adopted an aggressive strategy and used special purpose entities to fulfill a temporary or specific purpose to fund or manage risks associated with specific assets. Using this strategy Enron based on accounting, elected to disclose minimal accounting details on its use of "special purpose entities" [12].

${ }^{2}$ The CEO Bankruptcy Bonus, The Wall Street Journal, January 27, 2012, by Mike Spector And Tom McGinty, [online] Available at https://www.wsj.com/articles/SB10001424053111903703604576584480750545602 
Failures in the supply of accounting information attributable to the Board of directors, auditors and to the shareholders are important. The ways in which CEO uses or manipulates the accounting information should be rethought. According to [12], the case of Enron has illustrated that economists know surprisingly little about their incentives and information problems that arise in the governance and functioning of capital market intermediaries and the role these imperfections play in creating unsustainable jumps in stock market prices, incentives for overly aggressive and even fraudulent accounting and, more broadly, for mismanaged firms

\section{Duality and Control}

The chairman plays a key role in the company corporate governance. In case of control the chairman is balancing between CEO and the hidden information. The average performance of the latter is significantly higher than the average performance of the former. The ambivalence about the intertwined role of the CEO and chairman should be regulated by the board of directors. The board of directors is the collective body that should control the activities of CEO and chairman in either duality or unitary leadership structure. After all, the board of directors is the apex of control system, having the power to accept or ratify the CEO's and chairman's decisions. Therefore, the executive and non-executive directors should be able to exercise effective control. The non-executive directors are unable to exercise control effectively, unless they are independent from management and are ensure that they are provided among others, with unbiased accounting information. The board of directors entails the connection between the internal control of corporations and the stakeholders of the corporate accountability. Naturally, according to [4], there is information sharing cost that may confine the communication between $\mathrm{CEO}$ and non-executive chairman and the board of directors in extend. There is also an additional cost that arises from appointing an outside director chairman of the board that might reduce the agency costs of controlling the CEO's behavior, but it introduces the agency cost of controlling the behavior of the non-CEO chairman [4]. Duality of command reduces the cost of decision making, improves the reaction speed to external threats and makes the corporation strategy more flexible. One option being considered is to consolidate management leadership, centralizing power and control to reinforce the corporation against the external pressure [13]. Here, the question arises if the cost of sharing information and distress avoidance could be calculated against the cost of the business going bankrupt.

The company distress is associated with inefficient control over the company's management. Management and control are two separate actions; running a business is appointed to the management and governance is about controlling that it is running properly [10]. In extension board of directors is appointed to develop and the monitoring and controlling mechanism to ensure the effectiveness of the company running properly. The board of directors is not limited to its contribution in management but it is the agent which ensuing the sharehold- 
ers' investment. Controls of the CEO actions by the chairman and the CEO and chairman by the board of directors would be better and more effective because it helps overall control and monitoring. [14] assert that the members of board of directors establish a controlling mechanism to achieve the best possible performance, when they own shares in the company. This is due to the fact that owners have better access to information and specifically to accounting information. In controlling the accounting data, the board of directors solicits input and gives approval, scrutinizing the leadership of the firm. Therefore, in either case the board of directors is the regulators, and the controlling mechanism appointed by shareholders to execute their management duties and to control the head of the board and the CEO.

In the course of survey the research on duality, we try to convey additional information regarding the possibility of corporation distress, when there is duality or unitary leadership. This work provides a tool to those firms under $\mathrm{CEO} /$ chairman duality to calculate the possibility to bankrupt all others being stable. Early warnings of corporate distress are essential to control corporate governance. Failure to do so may lead the corporation to bankruptcy, resulting in losses to stockholders, creditors, customers and labor force. There are several studies, predicting corporate distress but this study, reversing the process, provides information from already bankrupt firm and adopts the Average Treatment Effects approach for a period of 11 years. Accordingly, this model provides information regarding the "lesson" from bankrupt firm with duality governance and not corporate survival probability.

\section{Analysis of the Bankruptcy Probability}

\subsection{Sample Selection}

We begin our empirical analysis by providing a detailed characterization of the leadership structure of 14.201 firms. For the needs of our work a sample of 283 bankrupt Greek companies operating in the trade and industrial sector during the period 2003-2014 was selected. At this point we notice that financial and accounting data for firms they went bankrupt is available, to the greatest extent, for two years from the event, hence, data availability ends to year 2014. Additionally, a sample of 13,918 "healthy" businesses was also selected from the same industries and over the same period. The total firm-year observations are 1575 for firms went bankrupt and 101,225 for healthy firms (Table 1).

Table 1. Sample classification with respect to the structure of the Board of Directors and the bankruptcy status.

\begin{tabular}{ccccccc}
\hline & \multicolumn{2}{c}{ Non-bankrupt } & \multicolumn{2}{c}{ Bankrupt } & \multicolumn{2}{c}{ Total } \\
\hline & $\#$ & $\%$ & $\#$ & $\%$ & $\#$ & $\%$ \\
CEO = chairman & 70,812 & 71.06 & 1162 & 73.78 & 71,974 & 71.10 \\
Otherwise & 28,838 & 28.94 & 412 & 26.22 & 29,250 & 28.90 \\
Total & 99,650 & & 1574 & & 101,224 & \\
\hline
\end{tabular}


The percentage of our sample companies in which the CEO was the same person as the chairman of the company's Board of Directors was $26.22 \%$ for the bankrupt and 28.94\% for the "healthy" firms (Table 1).

\subsection{Depended and Treatment Variables}

As a dependent variable we will use a binary variable named bankr which takes the value 0 when identifying the "healthy" firms in the sample and the value 1 when defining the firms went bankrupt.

We denote the time invariant dummy variable duality which equals 0 where Chief Executive Officer and Chairman are different persons and 1 where Chief Executive Officer is also the Chairman of the Board.

Thus, according to the above notation, our data base can be described as follows (Table 2).

\subsection{Control Variables}

Many bankruptcy prediction models have been proposed in accounting and finance literature. In these models, many variables are involved. The criteria with which the financial and accounting ratios were selected are their capability and their explanatory power as well as their frequency and popularity, with which they appear in the international literature covering all of the operational features of the company (Liquidity, Activity, Capital Efficiency, Capital Structure). Beginning with [15] [16] [17] and continuing through [18] [19] [20] [21] and [22] almost all factors that may influence the accuracy of the prediction of the models have been analyzed through empirical research. As a result of these studies financial ratios eventually became widely used in predicting corporate collapse. Totally, 8 control variables are selected for this study and are listed in detail below (Table 3 and Table 4).

Table 2. Sample classification with respect to duality and bankr variables.

\begin{tabular}{ccc}
\hline & Bankr \\
\hline Duality & 0 & 1 \\
1 & 70,812 & 1162 \\
0 & 28,838 & 412 \\
Total & 99,650 & 1574 \\
\hline
\end{tabular}

Table 3. Control variables description.

\begin{tabular}{cccc}
\hline Variable & Description & Variable & Description \\
\hline Ebitda_ta & EBITDA to total assets & Net profit margin & Net profits after taxes to sales \\
Debt ratio & Debt to total assets & Retain_ta & Retaining earnings to total assets \\
Current ratio & $\begin{array}{c}\text { Current assets to } \\
\text { short term liabilities }\end{array}$ & Sales_ta & Sales to total assets \\
Receivables turn Sales to accounts receivables & Size & Log of total assets. \\
\hline
\end{tabular}


Table 4. Descriptive statistics for control variables for the whole period of data.

\begin{tabular}{ccccc}
\hline Variable & Mean & Std. Dev. & Min & Max \\
\hline Bankr $=1$ & & & & \\
Sales_ta & 1.033 & 0.873 & 0.047 & 4.859 \\
Ebitda_ta & 0.082 & 0.106 & -0.231 & 0.485 \\
Debt ratio & 0.605 & 0.278 & 0.024 & 1.301 \\
Current ratio & 2.122 & 2.883 & 0.154 & 20.875 \\
Net profit margin & 0.019 & 0.167 & -0.654 & 0.587 \\
Receivables turn & 6.777 & 16.801 & 0.199 & 131.366 \\
Retain_ta & 0.048 & 0.264 & -1.185 & 0.640 \\
Bankr=0 & & & & \\
Sales_ta & 1.175 & 0.916 & 0.056 & 6.032 \\
Ebitda_ta & 0.048 & 0.098 & -0.376 & 0.334 \\
Debt ratio & 0.793 & 0.207 & 0.154 & 1.580 \\
Current ratio & 1.276 & 0.930 & 0.265 & 8.028 \\
Net profit margin & -0.042 & 0.213 & -1.389 & 0.236 \\
Receivables turn & 6.121 & 19.078 & 0.190 & 156.350 \\
Retain_ta & -0.036 & 0.271 & -1.592 & 0.354 \\
\hline
\end{tabular}

\subsection{Model Specification}

We apply a treatment effects procedure to estimate the average treatment effect of CEO duality on the binary outcome bankr while adjusting for the covariates represented by the financial ratios we have described in previous section. Moreover, to capture time specific effects we included as control variables a set of year dummies. Following [23] we use an augmented inverse-probability weighted (AIPW) estimator to identify and estimate the parameters of the potential-outcome distributions given that the potential outcomes and treatment are binary. In causal inference settings, doubly robust estimators involve models for both the propensity score and the conditional mean of the outcome. Because of the double-robust property, only one of these two models must be correctly specified for the AIPW estimator to be consistent [24]. According to this approach the estimation incorporates three steps; the first step includes the estimation of the parameters of the treatment model and also, the computation of the inverse-probability weights. In the second step, separate regression models of the outcome for each treatment level are estimated and the treatment-specific predicted outcomes for each subject are obtained. In the last step the weighted means of the treatment-specific predicted outcomes are computed, where the weights are the inverse-probability weights computed in the first step. The contrasts of these weighted averages provide the estimates of the average treatment effects (ATE).

Holding constant for the impact of the covariates and also adjusting for time 
effects we specify bankr $_{\text {it }}(0)$ as the base outcome to predict the probability of each treatment level as a function of the covariates:

$$
\operatorname{Prob}\left(\text { duality }_{\mathrm{it}}=j\right)=\frac{\mathrm{e}^{\beta_{j}^{\prime} X_{i}}}{\sum_{j=1}^{2} \mathrm{e}^{\beta_{j}^{\prime} X_{i}}}
$$

$j=1,2, i$ and $t$ represent, firms and the years of the sample and $x$. the vector of covariates,

$$
x=\left(\begin{array}{l}
\text { sales }_{\mathrm{ta}}, \text { ebitda }_{\mathrm{ta}}, \text { DebtRatio, currentratio, netprofitmargin, } \\
\text { receivablesturn, retain }_{\mathrm{ta}}, \text { year_dummies }
\end{array}\right)
$$

In Table 5 we present the results of the estimates of the mean of the distributions of the dependent variable bankr for each potential outcome with respect to the duality of the Board as determined by the duality variable. In particular, the estimates show in principle that the duality of the Board's impact is statistically significant on the probability of bankruptcy of businesses.

The results of Table 5 show that when the $\mathrm{CEO}$ and the Chairman of the $\mathrm{BoD}$ is the same person, then the probability that the company will go bankrupt increases by $0.0151(11.69 \%)$, in relation to the probability that the CEO and the Chairman of the BoD are different persons, i.e. from $7.10 \%$ to $8.00 \%$. Table 6 shows the probit outcome model coefficients for the untreated potential-outcome equation.

Table 7 represents the probit outcome model coefficients for the treated potential-outcome equation.

The coefficients of the treatment effect equation are used in the model to predict treatment statuses are presented in Table 8.

Table 5. Estimates of the mean of the distributions of the dependent variable bankr.

\begin{tabular}{ccccccc}
\hline bankr & Coef. & Std. Err. & $\mathrm{z}$ & $\mathrm{P}>|\mathrm{z}|$ & [95\% Conf. & Interval $]$ \\
\hline POmeans/dum_the_same & & & & & & \\
0 & 0.071 & 0.003 & 20.470 & 0.000 & 0.065 & 0.078 \\
1 & 0.080 & 0.002 & 34.410 & 0.000 & 0.075 & 0.084 \\
\hline
\end{tabular}

Table 6. Coefficients of outcome model for the untreated potential-outcome equation.

\begin{tabular}{ccccccc}
\hline & Coef. & Std. Err. & $\mathrm{z}$ & $\mathrm{P}>|\mathrm{z}|$ & {$[95 \%$ Conf. } & Interval $]$ \\
\hline Sales_ta & 0.027 & 0.047 & 0.560 & 0.572 & -0.066 & 0.119 \\
Ebitda_ta & -2.133 & 0.598 & -3.570 & 0.000 & -3.304 & -0.962 \\
Debt ratio & 2.298 & 0.283 & 8.130 & 0.000 & 1.744 & 2.852 \\
Current ratio & -0.034 & 0.019 & -1.730 & 0.083 & -0.072 & 0.004 \\
Net profit margin & -1.749 & 0.371 & -4.720 & 0.000 & -2.476 & -1.023 \\
Receivables turn & -0.002 & 0.004 & -0.540 & 0.587 & -0.010 & 0.006 \\
Retain_ta & 0.537 & 0.309 & 1.730 & 0.083 & -0.070 & 1.143 \\
\hline
\end{tabular}




\section{Continued}

\begin{tabular}{ccccccc}
\hline Year 2004 & -0.141 & 0.211 & -0.670 & 0.504 & -0.553 & 0.272 \\
Year 2005 & -0.303 & 0.212 & -1.430 & 0.154 & -0.719 & 0.113 \\
Year 2006 & -0.287 & 0.209 & -1.370 & 0.170 & -0.697 & 0.123 \\
Year 2007 & -0.222 & 0.200 & -1.110 & 0.268 & -0.614 & 0.171 \\
Year 2008 & -0.331 & 0.203 & -1.630 & 0.103 & -0.729 & 0.067 \\
Year 2009 & -0.642 & 0.220 & -2.910 & 0.004 & -1.073 & -0.210 \\
Year 2010 & -1.080 & 0.247 & -4.380 & 0.000 & -1.564 & -0.596 \\
Year 2011 & -1.470 & 0.276 & -5.320 & 0.000 & -2.011 & -0.928 \\
Year 2012 & -2.045 & 0.362 & -5.650 & 0.000 & -2.753 & -1.336 \\
Year 2013 & -3.818 & 0.997 & -3.830 & 0.000 & -5.771 & -1.865 \\
Year 2014 & -3.973 & 0.155 & -25.630 & 0.000 & -4.276 & -3.669 \\
Cons & -5.052 & 0.268 & -18.840 & 0.000 & -5.578 & -4.527 \\
\hline
\end{tabular}

Table 7. Coefficients of outcome model for the untreated potential-outcome equation.

\begin{tabular}{|c|c|c|c|c|c|c|}
\hline & Coef. & Std. Err. & $\mathrm{z}$ & $\mathrm{P}>|\mathrm{z}|$ & [95\% Conf. & Interval] \\
\hline Sales_ta & 0.061 & 0.036 & 1.690 & 0.090 & -0.010 & 0.132 \\
\hline Ebitda_ta & -1.930 & 0.387 & -4.990 & 0.000 & -2.688 & -1.172 \\
\hline Debt ratio & 2.813 & 0.167 & 16.890 & 0.000 & 2.487 & 3.140 \\
\hline Current ratio & -0.074 & 0.024 & -3.050 & 0.002 & -0.121 & -0.026 \\
\hline Net profit margin & -1.444 & 0.257 & -5.620 & 0.000 & -1.947 & -0.940 \\
\hline Receivables turn & -0.004 & 0.003 & -1.310 & 0.190 & -0.009 & 0.002 \\
\hline Retain_ta & 0.999 & 0.183 & 5.460 & 0.000 & 0.640 & 1.357 \\
\hline Year 2004 & -0.095 & 0.128 & -0.750 & 0.455 & -0.345 & 0.155 \\
\hline Year 2005 & -0.189 & 0.127 & -1.490 & 0.137 & -0.438 & 0.060 \\
\hline Year 2006 & -0.196 & 0.125 & -1.560 & 0.118 & -0.441 & 0.050 \\
\hline Year 2007 & -0.135 & 0.122 & -1.110 & 0.265 & -0.374 & 0.103 \\
\hline Year 2008 & -0.334 & 0.126 & -2.660 & 0.008 & -0.581 & -0.088 \\
\hline Year 2009 & -0.593 & 0.133 & -4.450 & 0.000 & -0.855 & -0.332 \\
\hline Year 2010 & -1.015 & 0.149 & -6.810 & 0.000 & -1.307 & -0.723 \\
\hline Year 2011 & -1.578 & 0.183 & -8.620 & 0.000 & -1.937 & -1.220 \\
\hline Year 2012 & -2.065 & 0.229 & -9.010 & 0.000 & -2.515 & -1.616 \\
\hline Year 2013 & -3.231 & 0.457 & -7.070 & 0.000 & -4.126 & -2.336 \\
\hline Year 2014 & -3.459 & 0.508 & -6.810 & 0.000 & -4.456 & -2.463 \\
\hline Cons & -5.360 & 0.170 & -31.610 & 0.000 & -5.693 & -5.028 \\
\hline
\end{tabular}


Table 8. Estimates of the treatment effect equation.

\begin{tabular}{|c|c|c|c|c|c|c|}
\hline & Coef. & Std. Err. & $\mathrm{z}$ & $\mathrm{P}>|\mathrm{z}|$ & [95\% Conf. & Interval] \\
\hline Sales_ta & -0.068 & 0.009 & -7.920 & 0.000 & -0.085 & -0.052 \\
\hline Ebitda_ta & 0.398 & 0.088 & 4.530 & 0.000 & 0.226 & 0.570 \\
\hline Debt ratio & 0.306 & 0.033 & 9.200 & 0.000 & 0.241 & 0.372 \\
\hline Current ratio & -0.010 & 0.003 & -3.640 & 0.000 & -0.015 & -0.005 \\
\hline Net profit margin & -0.153 & 0.054 & -2.830 & 0.005 & -0.260 & -0.047 \\
\hline Receivables turn & 0.000 & 0.000 & 0.010 & 0.988 & -0.001 & 0.001 \\
\hline Retain_ta & 0.068 & 0.032 & 2.110 & 0.035 & 0.005 & 0.132 \\
\hline Year 2004 & 0.033 & 0.036 & 0.910 & 0.361 & -0.038 & 0.104 \\
\hline Year 2005 & 0.040 & 0.036 & 1.120 & 0.262 & -0.030 & 0.111 \\
\hline Year 2006 & 0.054 & 0.036 & 1.500 & 0.132 & -0.016 & 0.123 \\
\hline Year 2007 & -0.002 & 0.035 & -0.050 & 0.958 & -0.070 & 0.067 \\
\hline Year 2008 & 0.010 & 0.035 & 0.290 & 0.773 & -0.058 & 0.079 \\
\hline Year 2009 & 0.022 & 0.035 & 0.620 & 0.534 & -0.047 & 0.091 \\
\hline Year 2010 & 0.016 & 0.036 & 0.440 & 0.662 & -0.054 & 0.086 \\
\hline Year 2011 & 0.016 & 0.036 & 0.440 & 0.658 & -0.055 & 0.088 \\
\hline Year 2012 & 0.010 & 0.037 & 0.270 & 0.784 & -0.063 & 0.084 \\
\hline Year 2013 & -0.023 & 0.039 & -0.590 & 0.558 & -0.098 & 0.053 \\
\hline Year 2014 & 0.085 & 0.039 & 2.180 & 0.029 & 0.009 & 0.161 \\
\hline Cons & 0.752 & 0.037 & 20.500 & 0.000 & 0.680 & 0.824 \\
\hline
\end{tabular}

\section{Conclusions}

The double role of this paper is to transfer the discussion from the firm performance to the concept of control. In current literature and from the empirical studies, the notion that prevails is that it is better to split the titles of CEO and chairman. One of the main issues concerns the leadership structure and performance. The argument is that separating the titles of CEO and chairman, the corporate performance will improve. The evidence recommended that the split of $\mathrm{CEO} /$ chairman titles strengthens corporate governance and improve performance. In contrast to the previous studies, we focused on the issue of internal control and that unitary leadership structure is associated with internal control of the firm. Unitary leadership improves transparency in accounting reports and enhances efficient control. Apart from the corporate governance structure, it should be noted that the board of directors has basically a triple role of its own, that is to say, it has a management function a monitoring function and the internal control function. Board of directors is the institution that can improve the overall tone of the company, improving the stakeholders' confidence, and can decrease the accounting irregularities that arose from the hidden information, the appreciation of the assets values and so on. 
Our empirical analysis provides new evidence on the effects of leadership structure, calculating the probability for a firm to go bankrupt. These data suggest that the probability in duality leadership structure increases. In writing this paper, we encounter many issues required further examination. Analyzing the literature and providing empirical results, maybe it does not give us convincing evidence, leaving the issue open for further research. We propose two future extensions compiled accordingly, with the dual nature of this paper.

First, considering the role of internal control, we propose further research of leadership organization, in order that the optimal leadership structure ensures the most efficient internal control. Adhere to this the role of accounting information, regarding its quality, a more detailed discussion of several other prominent issues that are involved in accounting irregularities, can be investigated.

Second, we tentatively propose the inclusion of bankruptcy cost against the unitary/duality operational cost, taking into account the probability for a firm to go bankrupt. Therefore, we propose the risk of bankruptcy cost to be added to the potential cost of separation or unitary leadership structure, taking into account the probability for a firm to go bankrupt and that this will be the separation or non-separation cost.

Finally, the continuous enlargement of corporations in the global market exacerbates the problem of internal control when corporations incorporate between countries and regions. In order for internal control to be exercised, a governance system has so far been applied, based on the existence of chief executives. Corporate governance using quantitative economics alters the qualitative characteristics, alleviating the strong local coherence. Accordingly, a new form of corporate governance, compatible with the requirements of corporations around the world remains in question.

\section{Conflicts of Interest}

The authors declare no conflicts of interest regarding the publication of this paper.

\section{References}

[1] Fama, E.F. and Jensen, M.C. (1983) Separation of Ownership and Control. The Journal of Law and Economics, 26, 301-325. https://doi.org/10.1086/467037

[2] Jensen, M. (1993) The Modern Industrial Revolution. Journal of Finance, 48, 831-880. https://doi.org/10.1111/j.1540-6261.1993.tb04022.x

[3] Daily, C.M., Dalton, D.R. and Cannella, A.A. (2003) Corporate Governance: Decades of Dialogue and Data. Academy of Management Review, 28, 371-382. https://doi.org/10.5465/amr.2003.10196703

[4] Brickley, J.A., Coles, J.L. and Jarrell, G. (1997) Leadership Structure: Separating the CEO and Chairman of the Board. Journal of Corporate Finance, 3, 189-220. https://doi.org/10.1016/S0929-1199(96)00013-2

[5] Kakabadse, N.K., Kakabadse, A. and Knyght, R. (2013) CEO/Chairman Role Duality Desire: Resistance to Separation Irrespective of Effect. In: Kakabadse A., Van den Berghe, L., Eds., How to Make Boards Work, Palgrave Macmillan, London, 311-341. 
https://doi.org/10.1057/9781137275707

[6] Kypriotelis, E. (2019) Trends in Directorate System and Control of Global Economy. Ph.D. Dissertation, University for National and World Economy, Sofia Bulgaria.

[7] Bornstein, M. (1979) Comparative Economics. Richard D. Irwin, Inc., Homewood Illinois.

[8] Mayer, C. (1997) Corporate Governance, Competition, and Performance. Journal of Law and Society, 24, 152-176. https://doi.org/10.1111/1467-6478.00041

[9] Shleifer, A. and Vishny, R. (1997) A Survey of Corporate Governance. The Journal of Finance, 52, 737-783. https://doi.org/10.1111/j.1540-6261.1997.tb04820.x

[10] Tricker, R.I. (1984) Corporate Governance: Practices, Procedures and Powers in British Companies and Their Boards of Directors. Gower Publishing Company, London.

[11] Lorsch, J.W. and Lipton, M. (1993) On the Leading Edge: The Lead Director. Harvard Business Review, 71, 79-80.

[12] Healy, M.P. and Palepu, G. (2003) The Fall of Enron. Journal of Economic Perspectives, 17, 3-26. https://doi.org/10.1257/089533003765888403

[13] Harrison, J.R., Torres, D.L. and Kukalis, S. (1988) The Changing of the Guard: Turnover and Structural Change in the Top Management Positions. Administrative Science Quarterly, 33, 211-232. https://doi.org/10.2307/2393056

[14] Coles, J.W., McWilliams V.B. and Sen, N. (2001) An Examination of the Relationship of Governance Mechanisms to Performance. Journal of Management, 27, 23-50. https://doi.org/10.1177/014920630102700102

[15] Altman, I.E. (1968) Financial Ratios, Discriminant Analysis and the Prediction of Corporate Bankruptcy. The Journal of Finance, 23, 589-609.

https://doi.org/10.1111/j.1540-6261.1968.tb00843.x

[16] Dambolena, I.G. and Khoury, S.J. (1980) Ratio Stability and Corporate Failure. The Journal of Finance, 35, 1017-1026. https://doi.org/10.1111/j.1540-6261.1980.tb03517.x

[17] Chen, K.H. and Shimerda, T.A. (1981) An Empirical Analysis of Useful Financial Ratios. Financial Management, 10, 51-60.

[18] Hillegeist, S.A., Keating, E.K., Cram, D.P. and Lundstedt, K.G. (2004) Assessing the Probability of Bankruptcy. Review of Accounting Studies, 9, 5-34. https://doi.org/10.1023/B:RAST.0000013627.90884.b7

[19] Agarwal, V. and Tafler, R. (2008) Comparing the Performance of Market-Based and Accounting-Based Bankruptcy Prediction Models. Journal of Banking and Finance, 32, 1541-1551. https://doi.org/10.1016/j.jbankfin.2007.07.014

[20] Li, M.Y.L. and Miu, P. (2010) A Hybrid Bankruptcy Prediction Model with Dynamic Loadings on Accounting-Ratio-Based and Market-Based Information: A Binary Quantile Regression Approach. Journal of Empirical Finance, 17, 818-833. https://doi.org/10.1016/j.jempfin.2010.04.004

[21] Doumpos, M., Niklis, D., Zopounidis, C. and Andriosopoulos, K. (2015) Combining Accounting Data and a Structural Model for Predicting Credit Ratings: Empirical Evidence from European Listed Firms. Journal of Banking \& Finance, 50, 599-607. https://doi.org/10.1016/j.jbankfin.2014.01.010

[22] Andrikopoulos, P. and Khorasgani, A. (2018) Predicting Unlisted SMEs' Default: Incorporating Market Information on Accounting-Based Models for Improved Accuracy. The British Accounting Review, 50, 559-573. 
https://doi.org/10.1016/j.bar.2018.02.003

[23] Robins, J.M., Rotnitzky, A. and Zhao, L.P. (1994) Estimation of Regression Coefficients when Some Regressors Are Not Always Observed. Journal of the American Statistical Association, 89, 846-866.

https://doi.org/10.1080/01621459.1994.10476818

[24] Słoczyński, T. and Wooldridge, J.M. (2018) A General Double Robustness Result for Estimating Average Treatment Effects. Econometric Theory, 34, 112-133.

https://doi.org/10.1017/S0266466617000056 